\title{
Photochemical Water Exchange of Rhodium(III) Complexes. II. Photochemical Water Exchange in Relation to Photoisomerization of cis- and trans- Tetraamminediaquarhodium(III) lons in Aqueous Perchloric Acid
}

\author{
L. Mønsted and L. H. Skibsted \\ Chemistry Department, Royal Veterinary and Agricultural University, Thorvaldsensvej 40, \\ DK-1871 Frederiksberg C, Denmark
}

\begin{abstract}
Mønsted, L. and Skibsted, L. H., 1986. Photochemical Water Exchange of Rhodium(III) Complexes. II. Photochemical Water Exchange in Relation to Photoisomerization of cis- and trans-Tetraamminediaquarhodium(III) Ions in Aqueous Perchloric Acid. - Acta Chem. Scand. A 40: 590-594.

Photoinduced isomerization and water exchange of the isomeric tetraamminediaquarhodium(III) ions have been studied at $25^{\circ} \mathrm{C}$ by irradiation at $366 \mathrm{~nm}$. The quantum yields for the isomerization reactions of cis- and trans- $\left[\mathrm{Rh}\left(\mathrm{NH}_{3}\right)_{4}\right.$ $\left.\left(\mathrm{OH}_{2}\right)_{2}\right]^{3+}$ in aqueous acidic $1.0 \mathrm{M}$ perchlorate solutions are $0.102 \pm 0.004$ and $0.0111 \pm 0.0007 \mathrm{~mol}^{\text {einstein }}{ }^{-1}$, respectively. With the assumption that photoisomerization is accompanied by water exchange in these complexes, the quantum yields for stereoretentive water exchange are $0.041 \pm 0.004$ and $0.0143 \pm$ $0.0011 \mathrm{~mol}^{\text {einstein }}{ }^{-1}$, respectively. All quantum yields are given per mole of rhodium(III) complex.
\end{abstract}

As a continuation of our studies of the mechanism for photoisomerization of ammineaquarhodium(III) complexes, ${ }^{1-6}$ we have labelled cis- and trans- $\left[\mathrm{Rh}\left(\mathrm{NH}_{3}\right)_{4}\left(\mathrm{OH}_{2}\right)_{2}\right]^{3+}$ with oxygen-18, and we report here the results of a study of the photochemical water exchange and photoisomerization of these complex ions in acidic aqueous $1.0 \mathrm{M}$ perchlorate solution following ligand field excitation.

\section{Experimental}

Chemicals. The compounds cis- $\left[\mathrm{Rh}\left(\mathrm{NH}_{3}\right)_{4} \mathrm{Cl}{ }_{2}\right] \mathrm{Cl}$. ${ }_{2}^{1} \mathrm{H}_{2} \mathrm{O},{ }^{7}$ trans $-\left[\mathrm{Rh}\left(\mathrm{NH}_{3}\right)_{4} \mathrm{Cl}_{2}\right] \mathrm{Cl} \cdot \mathrm{H}_{2} \mathrm{O},{ }^{8}$ cis- $[\mathrm{Rh}$ $\left.\left(\mathrm{NH}_{3}\right)_{4}\left(\mathrm{OH}_{2}\right)(\mathrm{OH})\right] \mathrm{S}_{2} \mathrm{O}_{6},{ }^{9} \quad$ trans- $\left[\mathrm{Rh}\left(\mathrm{NH}_{3}\right)_{4}\right.$ $\left.\left(\mathrm{OH}_{2}\right)_{2}\right]\left(\mathrm{ClO}_{4}\right)_{3}{ }^{8}$ and $\mathrm{Ag}$ (tos),${ }^{10}$ silver $p$-toluenesulfonate, were prepared as described previously. $98 \%{ }^{18} \mathrm{O}$-enriched $\mathrm{H}_{2} \mathrm{O}$ was supplied by Alfa Products. Other chemicals were of analytical grade.

Preparation of ${ }^{18} \mathrm{O}$-enriched tetraamminediaquarhodium(III) complexes. Enrichment of the complexes with ${ }^{18} \mathrm{O}$ was performed by silver ion-as- sisted chloride ligand aquation of the corresponding tetraamminedichlorido complexes in ${ }^{18} \mathrm{O}$-water at $70^{\circ} \mathrm{C}$, as described in detail previously. ${ }^{11}$

Photolysis experiments. These were performed by continuous photolysis techniques described previously, ${ }^{3}$ using cylindrical quartz cells thermostatted at $25^{\circ} \mathrm{C}$ and $366 \mathrm{~nm}$ light selected from a high-pressure mercury lamp by means of a Spindler and Hoyer interference filter. Light intensity was determined by ferrioxalate actinometry. ${ }^{12}$ Photoisomerization quantum yields were determined by photolysis of $5.3 \mathrm{ml}$ portions of $\sim 2 \mathrm{mM}$ solutions of either cis- or trans- $\left[\mathrm{Rh}\left(\mathrm{NH}_{3}\right)_{4}\right.$ $\left.\left(\mathrm{OH}_{2}\right)_{2}\right]^{3+}$. The photoreactions were interrupted periodically for spectrophotometric measurements. Water exchange quantum yields were determined by photolysis of $13.0 \mathrm{ml}$ of ${ }^{18} \mathrm{O}$-enriched complex solution. $10.0 \mathrm{ml}$ aliquots of the photolyzed solution were quickly frozen in liquid nitrogen and subsequently prepared for mass spectrometric analysis by sublimation in vacuum, as described previously. ${ }^{10}$ 


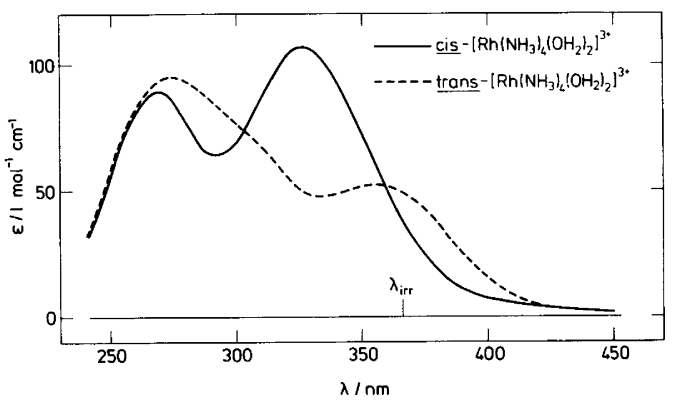

Fig. 1. Absorption spectra of cis- and trans-tetraamminediaquarhodium(III) complexes in aqueous $0.50 \mathrm{M} \mathrm{HClO}_{4}+0.50 \mathrm{M} \mathrm{NaClO}_{4}$.

$U V$-visible absorption spectra were recorded on a Cary Varian 219 spectrophotometer.

Mass spectrometric measurements were performed as described previously. ${ }^{10}$

Method of calculation. The method of calculation has been described in detail in Refs. 13-15. For the isomerization reactions, visible absorption spectra of mixtures measured from $250 \mathrm{~nm}$ to 500 $\mathrm{nm}$ at $10 \mathrm{~nm}$ intervals were employed to calculate reactant and product concentrations in the photolyzed solutions. ${ }^{13}$ In the last step of the calculations, data for all experiments were processed simultaneously to give quantum yields (Table 1). For the water exchange experiments, mass spectrometric $\delta$-values were converted to concentrations of coordinated oxygen-18, and the quantum yields determined for the isomerization reactions were used in the calculation of the quantum yields for stereoretentive water exchange $^{15}$ (Table 1 and Scheme 1). Examples of the agreement between observed and calculated curves are shown in Figs. 2 and 3.

\section{Results}

RHODIUM(III) COMPLEXES ॥

The UV-visible spectra of $c$ is-and trans- $\left[\mathrm{Rh}\left(\mathrm{NH}_{3}\right)_{4}\right.$ $\left.\left(\mathrm{OH}_{2}\right)_{2}\right]^{3+}$ are given in Fig. 1, and the absorption spectra of the photolyzed solutions of each isomer could, at any stage of the photolysis, be accounted for on the basis of linear combinations of the spectra of the pure isomers. Thermal isomerization was found to be negligible at $25^{\circ} \mathrm{C}$. In exhaustively photolyzed solutions, minor concentrations $(\sim 2 \%$ relative to $\mathrm{Rh}(\mathrm{III}))$ of ammonium ions could be detected by Nessler's reagent, ${ }^{16}$ indicating that ammonia photoaquation following prolonged irradiation results in the formation of triamminetriaquarhodium(III). For the photochemical isomerization reactions,

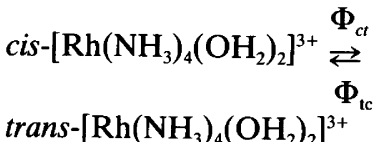

the estimated quantum yields, $\Phi_{c t}$ and $\Phi_{t c}$ are given in Table 1. Agreement was found between the experimental values for the concentrations calculated from the spectra and those calculated from the determined parameters, as shown in Fig. 2. The value for $\Phi_{t c}$ determined in the present study agrees with that previously reported, whereas the value for $\Phi_{c t}$ is significantly higher than the previous value. ${ }^{2}$ The previous investigation employed irradiation with light of wavelength $350 \mathrm{~nm}$ of poorer monochromicity than the $366 \mathrm{~nm}$ light used in the present study. Consequently, this new value is to be preferred. With the assumption that isomerization is accompanied by water exchange, the isomerization and water exchange reaction may be written as shown in Scheme 1. The quantum yields for stereoretentive water exchange, $\Phi_{c}$ and $\Phi_{t}$, were calculated

Table 1. Quantum yields for water exchange and isomerization of cis- and trans-[Rh $\left.\left(\mathrm{NH}_{3}\right)_{4}\left(\mathrm{OH}_{2}\right)_{2}\right]^{3+}$ in aqueous $0.50 \mathrm{M} \mathrm{NaClO}_{4}+0.5 \mathrm{M} \mathrm{HClO}_{4}$ at $25^{\circ} \mathrm{C}$ following $366 \mathrm{~nm}$ irradiation.

\begin{tabular}{|c|c|c|}
\hline Complex & Product & $\begin{array}{l}\text { Quantum yielda/ } \\
\text { mol einstein }^{-1}\end{array}$ \\
\hline $\operatorname{cis}-\left[\mathrm{Rh}\left(\mathrm{NH}_{3}\right)_{4}\left(\mathrm{OH}_{2}\right)_{2}\right]^{3+}$ & $\begin{array}{l}\text { cis- }\left[\mathrm{Rh}\left(\mathrm{NH}_{3}\right)_{4}\left(\mathrm{OH}_{2}\right)_{2}\right]^{3+} \\
\text { trans- }\left[\mathrm{Rh}\left(\mathrm{NH}_{3}\right)_{4}\left(\mathrm{OH}_{2}\right)_{2}\right]^{3+}\end{array}$ & $\begin{array}{l}\Phi_{c}=0.041(4) \\
\Phi_{c t}=0.102(4)\end{array}$ \\
\hline trans-[Rh $\left.\left(\mathrm{NH}_{3}\right)_{4}\left(\mathrm{OH}_{2}\right)_{2}\right]^{3+}$ & $\begin{array}{l}\text { cis- }\left[\mathrm{Rh}\left(\mathrm{NH}_{3}\right)_{4}\left(\mathrm{OH}_{2}\right)_{2}\right]^{3+} \\
\text { trans- }\left[\mathrm{Rh}\left(\mathrm{NH}_{3}\right)_{4}\left(\mathrm{OH}_{2}\right)_{2}\right]^{3+}\end{array}$ & $\begin{array}{l}\Phi_{t c}=0.0111(7) \\
\Phi_{t}=0.0143(11)\end{array}$ \\
\hline
\end{tabular}

\footnotetext{
asee Scheme 1.
} 
from the water exchange experiments using the quantum yields $\Phi_{c t}$ and $\Phi_{t c}$ determined from the isomerization experiments and rate constants for thermal water exchange (Table 2), and are given in Table 1. The quantum yields for total water exchange are: $\Phi_{c i s}^{*}=\Phi_{c}+\Phi_{c t}=0.143 \pm 0.004 \mathrm{~mol}$ einstein $^{-1} ; \Phi_{\text {trans }}^{*}=\Phi_{t}+\Phi_{t c}=0.0251 \pm 0.0008$ mol einstein ${ }^{-1}$. The agreement between the experimental values and the values calculated from the quantum yields is shown in Fig. 3 .

\section{Discussion}

The ammineaquarhodium(III) complexes, cisand trans- $\left[\mathrm{Rh}\left(\mathrm{NH}_{3}\right)_{4}\left(\mathrm{OH}_{2}\right)_{2}\right]^{3+}$ and cis- and trans$\left[\mathrm{Rh}\left(\mathrm{NH}_{3}\right)_{4}\left(\mathrm{OH}_{2}\right) \mathrm{Cl}\right]^{2+3,4}$ cis/trans-photoisomerize as a result of ligand field excitation in acidic solution forming photostationary states. For all of these complexes, oxygen-18 labelling studies have shown that photochemical water exchange occurs with quantum yields larger than those for cis/trans-photoisomerization. ${ }^{3}$ These observations can be rationalized by assuming that photoisomerization is a result of water exchange, and that stereomobile water exchange competes with stereoretentive water exchange. Similar competition between stereomobile and stereoretentive ligand substitution processes has been found for cis- and trans- $\left[\mathrm{Rh}\left(\mathrm{NH}_{3}\right)_{4} \mathrm{Cl}_{2}\right]^{+}$, which both give the photoproduct $\left[\mathrm{Rh}\left(\mathrm{NH}_{3}\right)_{4}\left(\mathrm{OH}_{2}\right) \mathrm{Cl}\right]^{2+}$ in the common cis/trans ratio of $0.22 \pm 0.03$. The same value is found for the cis/trans product ratio in the photochemical water exchange in both cisand trans-[ $\left[\mathrm{Rh}\left(\mathrm{NH}_{3}\right)_{4}\left(\mathrm{OH}_{2}\right) \mathrm{Cl}\right]^{2+}$. 3,4 The observation of a common cis/trans photoproduct ratio independent of both leaving ligand and reactant

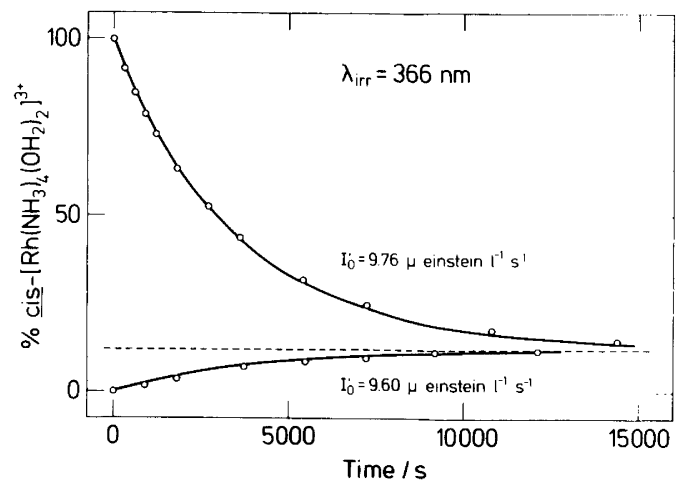

Fig. 2. Percentage of cis $-\left[\mathrm{Rh}\left(\mathrm{NH}_{3}\right)_{4}\left(\mathrm{OH}_{2}\right)_{2}\right]^{3+}$ during $366 \mathrm{~nm}$ photolysis at $25^{\circ} \mathrm{C}$ of $\sim 2 \mathrm{mM}$ aqueous solutions of cis- and trans- $\left[\mathrm{Rh}\left(\mathrm{NH}_{3}\right)_{4}\left(\mathrm{OH}_{2}\right)_{2}\right]^{3+}$, respectively $\left(0.50 \mathrm{M} \mathrm{HClO}_{4}+0.50 \mathrm{M} \mathrm{NaClO}_{4}\right)$. The points are experimental values derived from the multiwavelength spectral analysis of the reaction mixtures; the solid curves are calculated from the quantum yields (Table 1), the molar absorption coefficients at $366 \mathrm{~nm}\left(\varepsilon^{\text {is }}=38.2\right.$ and $\varepsilon^{\text {trans }}=49.0$ $\mathrm{M}^{-1} \mathrm{~cm}^{-1}$ ) and the light intensities $l_{\mathrm{o}}^{\prime}$.

stereochemistry has provided strong evidence that photosubstitution in octahedral $d^{6}$ electron configuration complexes of this type proceeds via either a single common excited state intermediate or a thermally equilibrated system of different excited state intermediates, all of reduced coordination number. ${ }^{4}$ According to this model, the intermediates generated by excited state water ligand dissociation from cis- $\left[\mathrm{Rh}\left(\mathrm{NH}_{3}\right)_{4}\left(\mathrm{OH}_{2}\right)_{2}\right]^{3+}$ and trans-[ $\left.\mathrm{Rh}\left(\mathrm{NH}_{3}\right)_{4}\left(\mathrm{OH}_{2}\right)_{2}\right]^{3+}$ should deactivate forming $\left[\mathrm{Rh}\left(\mathrm{NH}_{3}\right)_{4}\left(\mathrm{OH}_{2}\right)_{2}\right]^{3+}$ in a common cis/ trans ratio. The cis/trans photoproduct ratio for

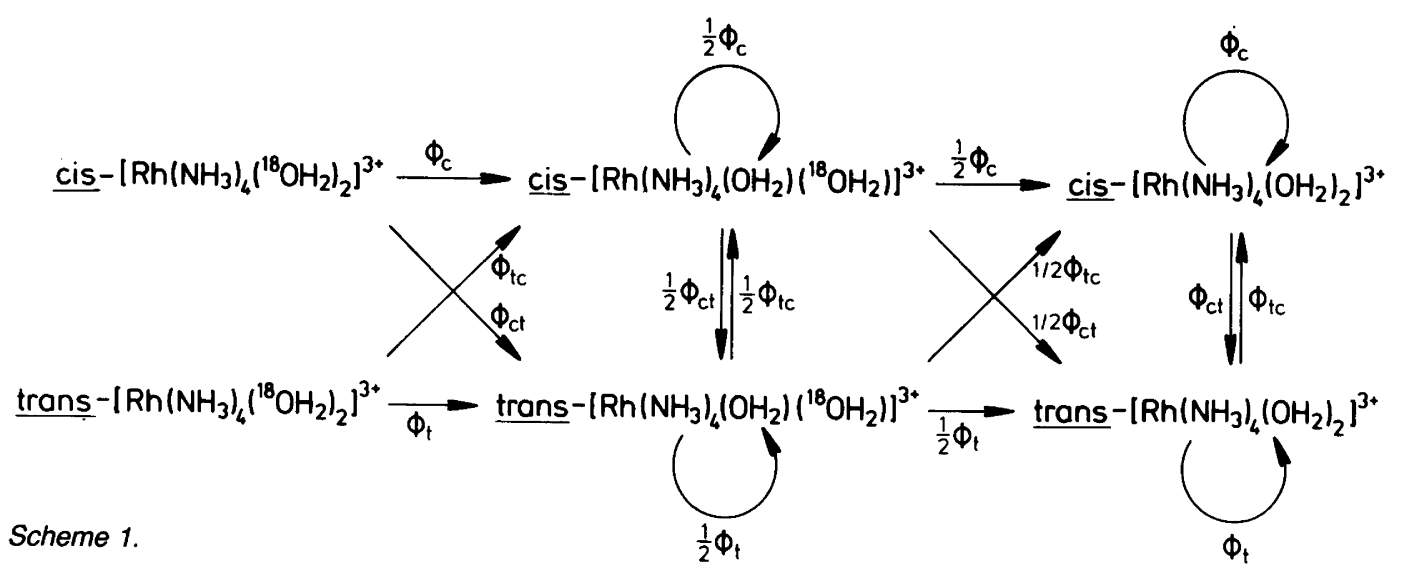


water exchange in trans- $\left[\mathrm{Rh}\left(\mathrm{NH}_{3}\right)_{4}\left(\mathrm{OH}_{2}\right)_{2}\right]^{3+}$ is calculated from the quantum yields of Table 1 as $\Phi_{t c} / \Phi_{t}=0.77 \pm 0.10$, a value which, although rather badly defined, does not differ significantly from the cis/trans photoproduct ratio $\Phi_{c} / \Phi_{c t}=$ $0.40 \pm 0.06$ calculated for water exchange in cis$\left[\mathrm{Rh}\left(\mathrm{NH}_{3}\right)_{4}\left(\mathrm{OH}_{2}\right)_{2}\right]^{3+}$. These results obtained for the isomeric diaqua complexes are thus not in disagreement with this model which postulates the formation of common excited state intermediates.

The low efficiency with which the isomeric tetraamminediaqua complexes exchange water and photoisomerize makes the cis/trans photoproduct ratios poorly defined. However, a situation in which the excited state intermediates do not attain equilibrium entails a cis/trans photoproduct ratio which is larger for cis- than for trans$\left[\mathrm{Rh}\left(\mathrm{NH}_{3}\right)_{4}\left(\mathrm{OH}_{2}\right)_{2}\right]^{3+}$, and this is clearly not observed. Alternatively, a certain degree of association in the transition state for photochemical reactions of the tetraamminediaquarhodium(III) complexes could be postulated. However, the present results do not justify proposing differences in the activation process for the tetraamminediaquarhodium(III) complexes relative to the previously investigated rhodium(III) complexes.

The photoproduct $\left[\mathrm{Rh}\left(\mathrm{NH}_{3}\right)_{4}\left(\mathrm{H}_{2} \mathrm{O}\right) \mathrm{Cl}\right]^{2+}$ is seen to have a stronger preference for the trans configuration than $\left[\mathrm{Rh}\left(\mathrm{NH}_{3}\right)_{4}\left(\mathrm{OH}_{2}\right)_{2}\right]^{3+}$, as concluded from the cis/trans ratios which are 0.22 and 0.54 (weighted mean of $0.77 \pm 0.10$ and 0.40 \pm 0.06 ), respectively. A mechanism for photoisomerization of rhodium(III) complexes in which pentacoordinate apical and basal tetragonal pyramids are in excited state equilibrium has been proposed: ${ }^{1,17-19}$

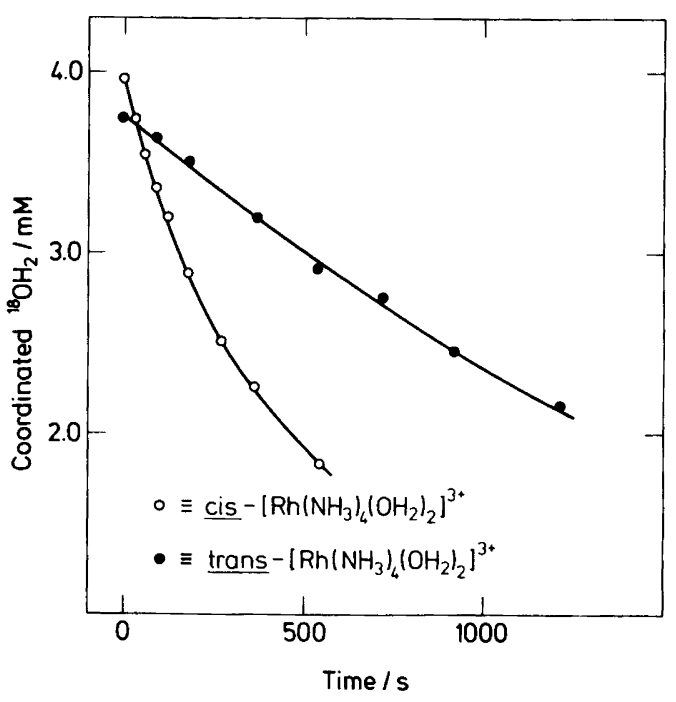

Fig. 3. Concentrations of coordinated ${ }^{18} \mathrm{OH}_{2}$ as a function of irradiation time. The points are the concentrations obtained from the mass spectrometric measurements and the curves are calculated from the determined quantum yields, the molar absorption coefficients at $366 \mathrm{~nm}$, the light intensity, the rhodium(III) concentration and the degree of oxygen-18 enrichment. The light intensity, the rhodium concentration and the degree of enrichment are $9.60 \mu$ einstein $I^{-1} \mathrm{~s}^{-1}, 2.20 \mathrm{mM}$ and $83 \%$ for the cis experiment and $9.73 \mu$ einstein $\mathrm{I}^{-1} \mathrm{~s}^{-1}, 2.38 \mathrm{mM}$ and $85 \%$ for the trans experiment.

$$
\text { apical }-\left[\mathrm{Rh}\left(\mathrm{NH}_{3}\right)_{4} \mathrm{X}\right]^{2+*} \stackrel{K^{*}}{\rightleftarrows} \text { basal- }\left[\mathrm{Rh}\left(\mathrm{NH}_{3}\right)_{4} \mathrm{X}\right]^{2+*}
$$

for which

$$
\frac{\text { [cis } \text { product }]}{\text { [trans } \text { product }]}=\frac{\Phi_{t c}}{\Phi_{t}}=\frac{\Phi_{c}}{\Phi_{c t}}=K^{*} \frac{k_{\mathrm{n}}(\text { basal })}{k_{\mathrm{n}}(\text { apical })}
$$

Table 2. Water exchange in ammineaquarhodium(III) complexes in acidic aqueous solution at $25^{\circ} \mathrm{C}$.

\begin{tabular}{llllll}
\hline Complex & $\begin{array}{l}\text { Thermal } \\
k^{a} / \mathrm{s}^{-1}\end{array}$ & Ref. & $\begin{array}{l}\text { Photochemical } \\
\Phi \% / m o l ~ e i n s t e i n^{-1}\end{array}$ & $\mathrm{k}^{c} \mathrm{~s}^{-1}$ & Ref. \\
\hline$\left[\mathrm{Rh}\left(\mathrm{NH}_{3}\right)_{5}\left(\mathrm{OH}_{2}\right)\right]^{3+}$ & $8.41(18) \times 10^{-6}$ & 22 & $0.43(3)$ & & 23 \\
cis- $\left[\mathrm{Rh}\left(\mathrm{NH}_{3}\right)_{4}\left(\mathrm{OH}_{2}\right)_{2}\right]^{3+}$ & $1.50(6) \times 10^{-5}$ & 11 & $0.143(4)$ & & This work \\
trans- $\left[\mathrm{Rh}\left(\mathrm{NH}_{3}\right)_{4}\left(\mathrm{OH}_{2}\right)_{2}\right]^{3+}$ & $1.42(6) \times 10^{-8}$ & 11 & $0.0251(6)$ & & This work \\
cis- $\left[\mathrm{Rh}\left(\mathrm{NH}_{3}\right)_{4}\left(\mathrm{OH}_{2}\right) \mathrm{Cl}^{2+}\right.$ & $2.38(3) \times 10^{-5 d}$ & 11 & $0.66(2)$ & $2.8(7) \times 10^{8}$ & 3,5 \\
trans- $\left[\mathrm{Rh}\left(\mathrm{NH}_{3}\right)_{4}\left(\mathrm{OH}_{2}\right) \mathrm{Cl}\right]^{2+}$ & $3.38(9) \times 10^{-5 d}$ & 11 & $0.39(4)$ & $1.8(5) \times 10^{8}$ & 3,5 \\
\hline
\end{tabular}

${ }^{a}$ First-order rate constants based on complex concentration. ${ }^{\circ} Q$ uantum yields based on complex concentration, cf. Scheme 1. Wavelength of irradiation $366 \mathrm{~nm}$, except for $\left[\mathrm{Rh}\left(\mathrm{NH}_{3}\right)_{5}\left(\mathrm{OH}_{2}\right)\right]^{3+}$ for which $313 \mathrm{~nm}$ light was used. ${ }^{\circ}$ Excited state ligand dissociation rate constants obtained from a combination of reaction quantum yields and luminescence lifetimes. ${ }^{d} \Delta H_{c i s}^{*}=102.9(1.3)$ and $\Delta H_{\text {trans }}^{*}=99.2(2.0) \mathrm{kJ} \mathrm{mol}^{-1}$. 
The cis/trans ratio given above can, however, only be regarded as an experimental determination of the equilibrium constant $K^{*}$ for the equilibrium between the basal and the apical isomers if one assumes equal deactivation rates [ $k_{\mathrm{n}}$ (basal) $=k_{\mathrm{n}}($ apical $\left.)\right]$ for the excited state isomers. ${ }^{1,20}$ Such an assumption draws at least some support from the lack of sensitivity to stereochemistry of the non-radiative deactivation of the hexacoordinated excited state precursors, which has been noted for several isomeric pairs of tetraaminerhodium(III) complexes. ${ }^{5,21}$ Angular overlap calculations $^{17-19}$ of the relative energies for these postulated apical and basal tetraammine intermediates show that the isomer having the weaker $\sigma$ donor strength ligand in the apical position has the lower energy. Chloride is a weaker $\sigma$-donor than ammonia, with water being intermediate, and the relative values of the estimates $K^{*}([\mathrm{Rh}$ $\left.\left.\left(\mathrm{NH}_{3}\right)_{4} \mathrm{Cl}\right]^{2+*}\right)=0.22$ and $K^{*}\left(\left[\mathrm{Rh}\left(\mathrm{NH}_{3}\right)_{4}\right.\right.$ $\left.\left.\left(\mathrm{OH}_{2}\right)\right]^{3+*}\right)=0.54$ are thus in agreement with the result of the angular overlap calculations.

In Table 2, thermal rate constants for water exchange in some rhodium(III) complexes are compared with the quantum yields for the corresponding photochemical reactions. The quantum yields are ratios of rate constants for individual deactivation processes. For the complexes of Table 2, excited state ligand dissociation rate constants have been determined only for cis- and trans- $\left[\mathrm{Rh}\left(\mathrm{NH}_{3}\right)_{4}\left(\mathrm{OH}_{2}\right) \mathrm{Cl}\right]^{2+} .{ }^{5}$ At $25^{\circ} \mathrm{C}$, the ground state rate is larger for trans- than for cis$\left[\mathrm{Rh}\left(\mathrm{NH}_{3}\right)_{4}\left(\mathrm{OH}_{2}\right) \mathrm{Cl}\right]^{2+}$, whereas the opposite is true for the excited state rates. Such behaviour has been termed antithermal; however, for the present cis/trans pair, it can be estimated from the activation parameters that the relative order of the thermal reactivity is reversed at $138^{\circ} \mathrm{C}$, suggesting, at least for these complexes, that the thermal reactions at elevated temperatures mimic the light-induced reactions.

Acknowledgements. This research was supported by grants from the Danish Natural Science Research Council and the Carlsberg Foundation.

The authors wish to thank Bodil Øby for technical assistance and the Geophysical Isotope Laboratory at the University of Copenhagen, in particular Dr. Niels Gundestrup, for carrying out the mass spectrometric analyses.
Drs. O. Mønsted and M. P. Hancock are thanked for helpful discussions, and we are grateful to Johnson Matthey for a loan of the rhodium used in these studies.

\section{References}

1. Skibsted, L. H., Strauss, D. and Ford, P. C. Inorg. Chem. 18 (1979) 3171.

2. Skibsted, L. H. and Ford, P. C. Inorg. Chem. 19 (1980) 1828.

3. Mønsted, L. and Skibsted, L. H. Acta Chem. Scand. Ser. A37 (1983) 663.

4. Mønsted, L. and Skibsted, L. H. Acta Chem. Scand. Ser. A 38 (1984) 535.

5. Sexton, D. A., Skibsted, L. H., Magde, D. and Ford, P. C. Inorg. Chem. 23 (1984) 4533.

6. Skibsted, L. H. Coord. Chem. Rev. 64 (1985) 343.

7. Hancock, M. P. Acta Chem. Scand. Ser. A29 (1975) 468.

8. Hancock, M. P. and Skibsted, L. H. Acta Chem. Scand. Ser. A 38 (1984) 87.

9. Hancock, M. P., Nielsen, B. and Springborg, J. Inorg. Synth. 24 (1986) 220.

10. Mønsted, L. and Mønsted, O. Acta Chem. Scand. Ser. A36 (1982) 259.

11. Mønsted, L. and Mønsted, O. Acta Chem. Scand. Ser. A38 (1984) 67.

12. Hatchard, C. G. and Parker, C. A. Proc. R. Soc. London A 235 (1956) 518.

13. Mønsted, L. and Mønsted, O. Acta Chem. Scand. Ser. A 32 (1978) 19.

14. Mønsted, L. and Mønsted, O. Acta Chem. Scand. Ser. A 38 (1984) 679.

15. Mønsted, L. and Mønsted, O. Acta Chem. Scand. Ser. A. Submitted for publication.

16. Vogel, A. I. A Textbook of Quantitative Inorganic Analysis, 3rd ed., Longman, London 1961, p. 783.

17. Vanquickenborne, L. G. and Ceulemans, A. Inorg. Chem. 17 (1978) 2730.

18. Vanquickenborne, L. G. and Ceulemans, A. Inorg. Chem. 20 (1981) 110.

19. Purcell, K. F., Clark, S. F. and Petersen, J. D. Inorg. Chem. 19 (1980) 2183.

20. Petersen, J. D. Inorg. Chem. 20 (1981) 3123.

21. Skibsted, L. H., Hancock, M. P., Magde, D. and Sexton, D. A. To be published.

22. Swaddle, T. W. and Stranks, D. R. J. Am. Chem. Soc. 94 (1972) 8357.

23. Ford, P. C. and Petersen, J. D. Inorg. Chem. 14 (1975) 1404.

Received May 26, 1986. 